\title{
A SZÉKELYFÖLDI MEGYÉK ÖNKORMÁNYZATI FORRÁSAI
}

\author{
(The Resources of the Local Authorities in the Szeklerland \\ Counties)
}

\author{
NAGY ISTVÁN
}

\begin{abstract}
Kulcsszavak:
Székelyföld önkormányzati források saját források állami transzferek

Romániában az 1990-es politikai változás és az ezzel járó gazdasági fejlödés a kormányzat gazdasági szerepét is folyamatosan növelte, igy szükségszerüvé vált a közösségi szektor pénzügyeinek és finanszírozásának megváltozása. A politikai és gazdasági hatalom elkülönésével párhuzamosan egyre több feladat került az állami kormányzattól helyi, városi-megyei hatáskörbe. Az állami támogatások mellett megjelent a saját forrás, ezen belül olyan helyi adók kivetésének lehetösége, amelyeknek nagyságát az önkormányzatok (stratégiájuk függvényében) változtathatják is.

Jelen tanulmány a romániai önkormányzati finanszirozási rendszert elemzi, továbbá a romániai, ezen belül a székelyföldi megyék adóbevételeinek nagyságát, szerkezetét, illetve az illetó megyék állami transzfereinek mértékét igyekszik bemutatni.
\end{abstract}

\section{Bevezetés}

A tỏkés piacgazdaság fejlödésével a kormányzat gazdasági szerepvállalása növekvő szerepet mutat. Habár a Wágner törvényként ismert, a kormányzati szektor növekedését állandó folyamatnak tartó paradigma nem fenntartható (Văcărel et al. 2007), hiszen a közkiadások a végtelenségig nem növekedhetnek, a növekedés mégis kézzelfogható (pl. az Egyesült Államokban a kormányzati kiadások GDP aránya az 1937. évi 8,6\%-os arányról 1996-ra 33,3\%-os arányra növekedett). A növekedést elsősorban a demográfiai (pl. aktív munkaerö csökkenése), a technikai-technológiai (közmüvek iránti igények növekedése), a női foglalkoztatás elterjedése (családi támogatási rendszerek iránti igény), a munkanélküliség növekedése, az oktatás és egészségügy iránti igény robbanásszerü fejlődése, a területi egyenlőtlenségek kiegyenlitése, a termelő és fogyasztói szubvenciók iránti igény növekedése, az állami foglalkoztatottak bérének növelése (a versenyszektor és az állami szektor közötti bérkülönbségek csökkentése) váltotta ki (Vigvári 2008). Az elmúlt száz évben a kormányzat gazdasági rendszerekben játszott szerepe is jelentősen változott. Az a kormányzat a legjobb-e, amelyik a legkevésbé kormányoz? kérdés megválaszolására különböző modellek és irányzatok keletkeztek, kezdve az Adam Smith gondolatain alapuló klasszikus modelltöl (minimális kormányzati szerep), az aktivista állam (a városba áramlás miatt megnőtt igények), illetve a szocialista modellig. Az utóbbi modell, illetve a kommu- 
nista rendszernek a kormányzat szerepéről vallott felfogása, állami tulajdon és a társadalmi jólét elosztásában játszott szerepe, még évekkel a rendszer felbomlása után is egyfajta filozófiai ideáltípust képvisel sok-sok (a parlamenti választások eredményét vizsgálva), az átalakulást fảjdalmas eseménysorozatként megélő állampolgár számára (Nemec-Wright 2000).

Az 1990-es politikai változás és az ezzel párhuzamosan történő gazdasági fejlődés Romániában is szükségszerüvé tette a közösségi szektor pénzügyeinek, finanszírozásának változását. A politikai és gazdasági hatalom elkülönésével párhuzamosan egyre több feladat került az állami kormányzattól helyi, városi-megyei hatáskörbe. A decentralizációs törekvések célja egyes feladatok ellátása olyan szinten, ahol ezeket a szolgáltatásokat igénybe veszik. Ez a helyi önkormányzatok finanszírozásának változását feltételezte. Az állami támogatások mellett megjelent a saját forrás: olyan helyi adók kivetésének lehetősége, amelyek nagyságát az önkormányzatok (stratégiájuk függvényében) változtathatják is.

A tanulmány elsősorban rövid áttekintést kíván adni a romániai önkormányzati finanszírozási rendszerről, másodsorban pedig a publikusnak számító, de sehol közzé nem tett megyei adóbevételek nagyságát, szerkezetét, a saját és az állami transzferek mértékének és arányának vizsgálatát célozza.

A téma romániai kutatási háttere szegényes. Sokan foglalkoznak a téma jogi oldalával, gazdasági oldalával azonban annál kevesebben. Romániai forrásanyag keresése közben inkább tankönyv jellegủ munkákat találtunk, igazi kutatási és elemzési munkák, amelyben az önkormányzati adók területi eloszlásának a vizsgálata is szerepet kapna, nem léteznek. A legtöbb kutató a közpénzügyek rendeltetésérỏl, elveiről, struktúrájáról, az állami és helyi költségvetések tervezéséröl, végrehajtásáról és ellenörzéséről, a különböző önkormányzati és állami bevételek és kiadások típusairól, illetve a decentralizációs törekvésekről ír. A legjobb kutatási munkák Iulian Văcărel, Nicolae Hoanţă, Adrian Inceu és Ion Stancu nevéhez füzödnek, Constantin Tulai, Tatiana Moşteanu, Lucian Tatu munkái pedig teljességével tankönyv jellegüek. Egy szakértő sem szentel különös figyelmet az önkormányzati adók nagyságának és területi megoszlásának a kutatására. Az ilyen szintủ kutatás hiánya két okra vezethető vissza. Az egyik ok az adatok nehéz hozzáférhetősége, a másik ok pedig az lehet, hogy a kőzpénzügyek kutatása a legtöbb romániai egyetemen a közigazgatási tanszéken belül történik, ahol nem szentelnek elég figyelmet a területiség kutatására. Ebből a szempontból Geréb Lászlónak a „Székelyföld” tanulmánykötetben megjelent írása és az abban feltárt adatok úttörő jellegüek (Geréb 2003).

Az elemzés során, Székelyföldön Hargita, Kovászna és Maros megyét fogjuk érteni. Habár Maros megyének csak egy része tartozik a történelmi Székelyföldhöz, vizsgálatát fontosnak tartjuk mind a Székelyföld legnagyobb városa, Marosvásárhely vonzáskörzete szempontjából, mind abból a szempontból, hogy Maros megye magyar ajkú lakosainak száma (228 ezer) meghaladja Kovászna megye összlakosságát (222 ezer). A Közép régióban található $17000 \mathrm{~km}^{2}$-en fekvő Székelyföld (6 $639 \mathrm{~km}^{2}$ Hargita megye, $6714 \mathrm{~km}^{2}$ Maros megye, $3710 \mathrm{~km}^{2}$ Kovászna megye) megközelítőleg 1,1 millió lélekszámából 670 ezer fő magyar (276 ezer Hargita 
megyében, 228 ezer Maros megyében, 164 ezer Kovászna megyében), és 407 ezer fớt tesz ki a román ajkú lakosság (2002. évi népszámlálási adatok alapjản).

\section{Önkormányzati pénzügyek}

A helyi közigazgatási törvényekkel párhuzamosan, ezekre épülve a mindenkori kormányok stratégiája függvényében jelentek meg a helyi önkormányzatok pénzügyeit szabályozó törvények is.

A közép-európai átmeneti országokban legelterjedtebb unitárius rendszer ${ }^{1}$ (Nemec-Wright 2000) formában müködik Románia is (Georgescu 2009), és jelenleg a fejlett országok standardjához igazított adózási rendszere van. A nemzeti költségvetésnek három nagy alappillére van: az állami költségvetés ${ }^{2}$, a társadalombiztosítási költségvetés és az önkormányzatok költségvetései. Ezek mellett még hét kisebb költségvetés és elkülönített alap létezik, amelyek elsődleges célja a speciális feladatok ellátása (Georgescu 2009).

Az önkormányzatok finanszírozásának szabályozása a 2006. évi 273-as önkormányzatok finanszírozásáról szóló, valamint a 2006. évi 195-ös decentralizációs törvények révén történik. Ezek a törvények tartalmazzák a helyi közigazgatás jövedelem-forrásait, a saját és az állami transzferek rendszerét, a közintézmények pénzügyi forrásrendszerét, a feladatok, valamint az egyes intézményekre, önkormányzatokra háruló költségek típusainak felsorolását. A 2006. évi 273-as törvény tartalmazza az egyes állami transzferek (személyi jövedelemadóból való visszautalások nagyságát) mértékét és arányát, az adótörvénykönyv pedig a helyi adók mértékét szabályozza.

A kormányzati szintek közötti decentralizáció változásai a fejlett piacgazdaságok (vegyes gazdaságok) által fölépített jóléti állam fejlódési szakaszaihoz kötődnek. Ebben az általánosnak tekinthető folyamatban a regionális és különösen a helyi kormányzatok feladatrendszere folyamatosan bővült, miközben a feladatok ellátásához szükséges erőforrások nem változtak, sőt esetenként szükültek (Lados 1995).

A feladatrendszer valamilyen szintü leosztása és bővülése a romániai helyi közigazgatások esetében is érvényesült. A 2006. évi 195-ös decentralizációs kerettörvény megkülönböztet exkluzív, megosztott és leosztott feladatokat ${ }^{3}$.

\section{Az önkormányzati gazdálkodás forrásrendszere}

A helyi önkormányzatok müködésének alapvető célja, hogy helyi közszolgáltatásokat biztosítson polgárai számára. A gazdasági fejlettségtől és a rendszertől függetlenül meghatározható egy forrásrendszer, amely lehetővé teszi e feladatok ellátását a helyi önkormányzatban. Ez négy elemből álló rendszer, amelyben az egyes tényezők funkciója jól meghatározható, azonban alkalmazásuk tényleges arányait befolyásolja az adott ország fejlettsége, hagyományai, a helyi önkormányzati apparátus felkészültsége, illetve a kormányzati hatalom és felelősség, továbbá ahhoz kötődően a forrásképzés decentralizációjának mértéke a központi és az alsóbb kormányzati szintek 
között. Ennek a normatív forrásrendszernek az elemei a következök: használati dijak, helyi adók, kormányzati transzferek, kölcsön források (Lados 1995).

A helyi önkormányzatokra kettős gazdasági szerep hárul: a közösségi feladatok szervezése és finanszírozása (közüzemi szolgáltatások használati dijakon és helyi adókon keresztül) és az egyes települések gazdasági fejlődésének segítése. E feladatok elvégzésében segít az állami transzferrendszer, amelynek szerepe elsősorban az, hogy forrásokat biztosítson olyan önkormányzati közfeladatok elvégzésére, amelyekre a helyi szervezeteknek nincs forrása (csak egyes társadalmi csoportokat érintő közszolgáltatások), másodsorban, hogy a regionális fejlettségi különbségeket csökkentse. A helyi adók korlátossága miatt minél nagyobb a területi különbség, annál nagyobb az állami transzferek szerepe. Ugyanakkor minél nagyobbak az állami transzferek, annál kisebb a kormányzati decentralizáció, vagyis a kormányzati decentralizáció egyik mérőszáma a helyi adók mértéke a helyi bevételekben.

Habár Romániában az elmúlt 15 évben a saját források kb. 20\%-át adják az összjövedelemnek, az állami transzferek aránya nagyjából ugyanazon szinten, $80 \%$ körül maradt (1. táblázat). A saját forrásokat vizsgálva kitünik, hogy a helyi adók aránya folyamatosan csökkent, az 1991. évi 94\%-ról 2005-re 68\%-ra.

\section{TÁBLÁZAT}

A helyi önkormányzatok bevételi szerkezete, 1991-2005 (\%)

(The Structure of the Income of Local Authorities between 1991-2005)

\begin{tabular}{lcccccc}
\hline Helyi önkormányzati források & 1991 & 1994 & 1997 & 2000 & 2003 & 2005 \\
\hline $\begin{array}{l}\text { Saját források } \\
\text { (építményadó, telekadó, gépko- } \\
\text { csiadó, közszolgálati intézmények }\end{array}$ & 28,8 & 19,0 & 19,0 & 25,8 & 18,8 & 19,5 \\
$\begin{array}{l}\text { profitjja, töke-jövedelmek, egyéb } \\
\text { adók) } \\
\quad \text { ebböl helyi adók }{ }^{4}\end{array}$ & 94,1 & 84,5 & 76,8 & 71,3 & 75,8 & 68,1 \\
\hline Hitelek & 0,0 & 0,0 & 0,5 & 0,1 & 1,9 & 0,1 \\
\hline $\begin{array}{l}\text { Kormányzati transzferek- } \\
\text { támogatások }\end{array}$ & 69,5 & 81,0 & 80,9 & 74,2 & 81,2 & 80,4 \\
\hline Egyéb jövedelmek & 1,7 & 0,1 & 0,0 & 0,0 & 0,0 & 0,1 \\
\hline
\end{tabular}

Forrás: A Romániai Statisztikai Hivatal adatai alapján saját számítás.

A helyi adók aránya az összjövedelemhez viszonyítva ugyancsak fokozatosan visszaesett, az 1991-es 27,1\% arányról a 13,2\%-os 2005. évi értékre. Ez az arány jóval az OECD-országok aránya alatt van, ahol a legtöbb ország esetében a helyi adók aránya a helyi jövedelmekben $30 \%$ és $70 \%$ között mozog. A romániai értékeket azonban torzítják az oktatásnak utalt ÁFA-beli transzferek, ugyanis ezek a transzferek célirányos transzferek és csak az oktatásügyben felmerült költségekre fordíthatók (az önkormányzatok csak pénzügyi csatorna szerepét játsszák). Ha az oktatásnak szánt ÁFA visszautalást nem számítjuk önkormányzati jövedelemnek, akkor 2005-ben a helyi adó aránya elérte az összbevétel 24\%-át. 


\section{Az önkormányzatok költségvetésének területi szerkezete}

Az önkormányzatok bevételeit és kiadásait az adott önkormányzatok költségvetése tartalmazza. A helyi költségvetés a helyi bevételek és kiadások előirányzatainak rögzítésére szolgáló, kötelezettségeket tartalmazó dokumentum, amely az önkormányzati feladatok ellátásának kereteit szabályozza. A helyi költségvetés tehát az önkormányzat múködésének pénzügyi feltételeit határozza meg, ugyanakkor a rögzített előirányzatokon keresztül a helyi feladatok ellátásának irányítási, finanszírozási és ellenörző rendszere (Geréb 2003).

\section{A helyi önkormányzatok jövedelme és ezek területi megoszlása}

Romániában a helyi önkormányzatok egy fỏre jutó összjövedelmének területi megoszlását vizsgálva látható, hogy az erdélyi és a bánáti megyéknek (kivéve Szilágy megyét) jóval nagyobb összbevételük van, mint Románia moldvai, illetve havasalföldi megyéinek (1. ábra).

\section{1. ÁBRA}

A helyi önkormányzatok egy före jutó bevételei, 2005 (euró) (Local Authorities Income per Capita, 2005 [EUR])

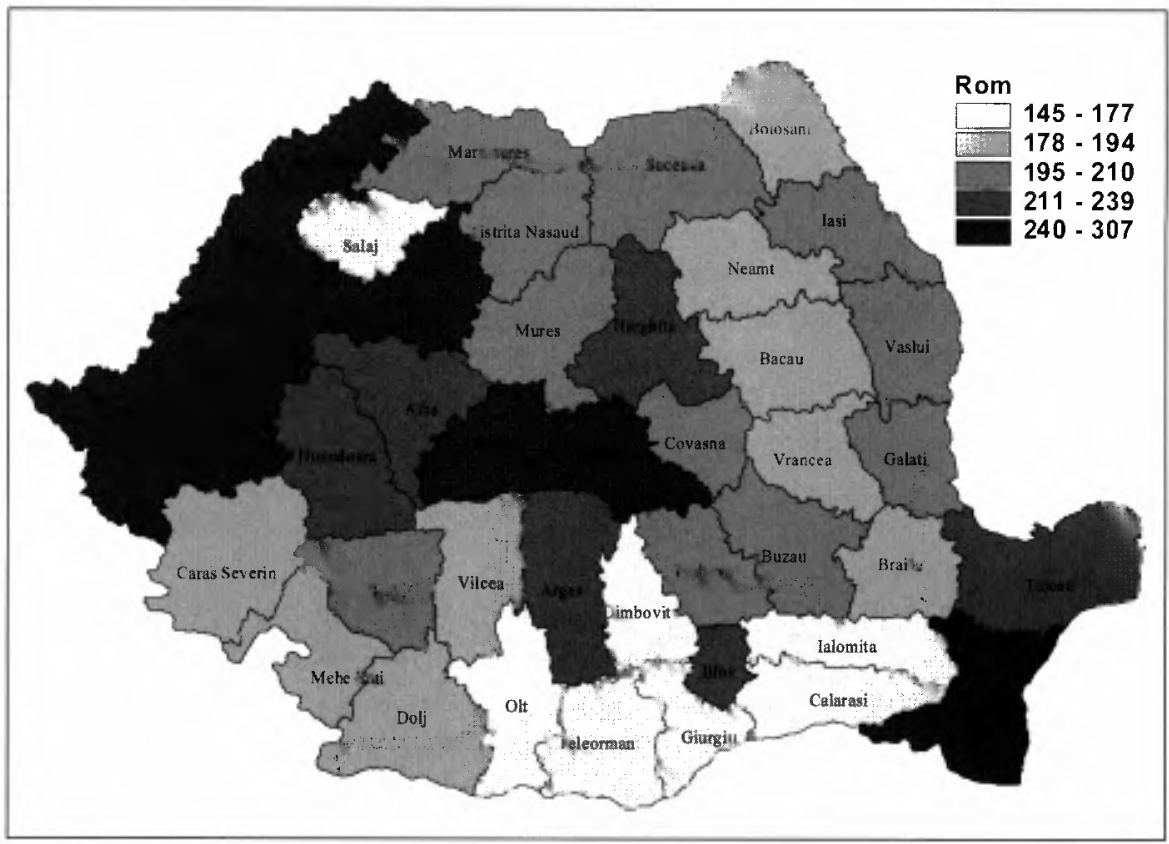

Forrás: A Pénzügyminisztérium által szolgáltatott adatok alapján saját szerkesztés. 
A legnagyobb helyi önkormányzati egy före eső jövedelmet Szatmár megye könyvelheti el magának, Hargita a romániai 42 megyéböl az elökelö 10., Kovászna a 16., Maros megye pedig a 17. helyen áll. Mindhárom székely megye azonban az országos átlag alatt van. Az országos átlagnál $(6,3 \%)$ valamivel jobb arányt ért el Hargita $(7,3 \%)$ és Kovászna (6,6\%) megye, ha az összjövedelmet a GDP-hez arányítjuk, Maros megye pedig 5,7\%-kal jóval az átlag alatt teljesített. Ezek a helyezések azonban önmagukban semmit nem mondanak, ha figyelembe vesszük a helyi önkormányzatok bevételeinek két nagy alkotórészét. Amíg az önkormányzatok saját forrásaikat kezelni és bizonyos esetben változtatni is tudják, addig a kormányzati transzferek, a dekoncentrált intézmények forrásainak nagysága soktényezős.

\section{Saját források}

A saját források legfontosabb komponensét a helyi adók csoportja képviseli (2. táblózat). Ez a saját forrás $68 \%$-át képezi, amelyen belül megkülönböztethetünk direkt és indirekt adókat. A direkt adók (a helyi adók 77\%-a) közül a legfontosabbak a különböző lakossági és vállalati vagyonadók (jármü és ingatlanadók), az indirekt adók közül pedig a különböző események utáni jegyadókat, különbözon engedélyek kibocsátási illetékét, a különböző bélyegeket említhetjük stb. A saját források közé tartozik még a helyi érdekeltségủ közintézmények profitja és egyéb közintézményi jövedelmek, valamint az önkormányzati vagyongazdálkodásból származó jövedelmek.

\section{TÁBLÁZAT}

A helyi önkormányzatok saját forrásainak struktúrája, 2005 (millió euró)

(The Structure of the Local Authorities' own Resources in 2005, million EUR)

\begin{tabular}{|c|c|c|c|c|c|c|c|c|c|c|c|}
\hline \multirow[b]{3}{*}{$\begin{array}{l}\text { Összes } \\
\text { saját } \\
\text { forrás }\end{array}$} & \multicolumn{9}{|l|}{ amelyből: } & \multirow{3}{*}{ 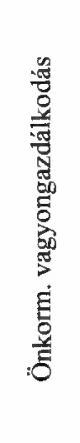 } & \multirow{3}{*}{ 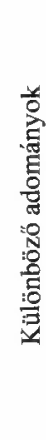 } \\
\hline & \multirow[b]{2}{*}{$\begin{array}{l}\text { Helyi } \\
\text { adók } \\
\text { (fiskális } \\
\text { adók) }\end{array}$} & \multicolumn{7}{|l|}{ amelyböl: } & \multirow{2}{*}{ 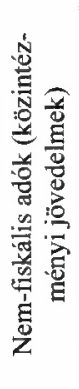 } & & \\
\hline & & $\begin{array}{l}\text { Direkt } \\
\text { adók }\end{array}$ & $\begin{array}{c}\text { Helyi önk. } \\
\text { vállalatainak } \\
\text { profitja }\end{array}$ & 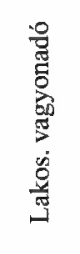 & 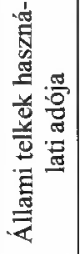 & 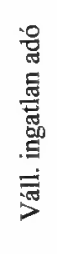 & 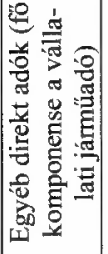 & 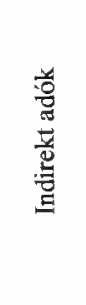 & & & \\
\hline 979,8 & 666,9 & 510,1 & 10,6 & 211,7 & 3,5 & 241 & 43,1 & 156,8 & 203 & 109,8 & 6,4 \\
\hline
\end{tabular}

Forrás: A Pénzügyminisztérium által szolgáltatott adatok alapján saját szerkesztés.

A helyi adók nagyságát a mindenkori adótörvénykönyv szabályozza, mely szerint a helyi önkormányzatok számottevően csak a vállalkozásokra kivetett épületadót határozhatják meg nagy szabadságfokkal. Az önkormányzatok (helyi tanács) a vállalati épületadót $0,25 \%$ és $1,5 \%$ között határozhatják meg az ingatlan könyvelésben 
szereplö leltári értékére számolva. A törvény azt is kimondja, hogy ha az ingatlan az elmúlt három évben nem volt újraértékelve, akkor az adó a könyvelési értékre számolódik, természetesen az első felértékelésig, értéke a helyi tanács határozata alapjản pedig 5-10\% lehet. Ez számos visszaéléshez vezethet és vezet is, mely a helyi vállalkozókat negatívan érinti. Ugyanis, ha egy helyi vállalkozó vásárol egy nagyobb érékủ ingatlant és nincs tudomása arról, hogy három évenként az ingatlant fel kell értékelni, arra számíthat, hogy hatalmas, akár az ingatlan értékének a 10\%-át kitevő adót kell befizetnie a helyi önkormányzatnak. A törvény nem kötelezi az önkormányzatokat, hogy az újraértékeltetésről az adóbefizetőt értesítsék.

\section{TÁBLÁZAT}

A helyi önkormányzatok jövedelmeinek szerkezete a Székelyföldön, 2005 (millió euró) (The Structure of the Income of Local Authorities from Szekler Counties in 2005, million EUR)

\begin{tabular}{lcccc}
\hline \multicolumn{1}{c}{ Jövedelem } & $\begin{array}{c}\text { Maros } \\
\text { megye }\end{array}$ & $\begin{array}{c}\text { Kovászna } \\
\text { megye }\end{array}$ & $\begin{array}{c}\text { Hargita } \\
\text { megye }\end{array}$ & Románia \\
\hline Saját források & 23 & 7 & 10 & 980 \\
Állami transzferek & 98 & 39 & 63 & 4052 \\
Összjövedelem & 121 & 46 & 73 & 5032 \\
\hline
\end{tabular}

Forrás: A Pénzügyminisztérium által szolgáltatott adatok alapján saját szerkesztés.

A helyi adók arányában a vállalatokra valamivel nagyobb teher jut, mint a lakosságra. A vállalati adók a helyi adók $43 \%$-át teszik $\mathrm{ki}^{6}$, míg a lakosság által fizetett adók aránya $30 \%$. A sajátos adózási rendszer adóexportot és önkormányzatok közötti versenyt nem eredményezhet, hiszen az egyetlen mérvadó adónem, amellyel az önkormányzatok befolyásolni tudják a helyi piacot, az a vállalati épületadó, és ennek mértéke mindenütt nagyjából ugyanaz.

Ha a helyi önkormányzatok saját forrásainak (a személyi jövedelemadó nélkül, amely jelen tanulmányban állami transzferként szerepel) területi, megyei bontását vizsgáljuk, kiderül, hogy abszolút mértékben Kovászna és Hargita jóval az átlagnál kevesebb saját forrással rendelkezik (3. táblázat), de ez az átlagosnál kisebb lakosságszámának is köszönhetö. A székely megyék közül Kovászna Románia utolsó elötti megyéje, Hargita pedig a 31. helyezést érte el, Maros megye pedig egy előkelö 13. helyezést. Ha az önkormányzati saját forrásokat elosztjuk az egyes megyékben élő személyek számával, akkor a rangsor alapvetően megváltozik a kevésbé sủrün lakott megyék javára. Kovászna megye a 22., Hargita a 24., az átlagosan sủrün lakott Maros megye helyezése sokat nem változott (14.). A vizsgált székely megyék hasonló helyezéseket értek el az egy fóre eső helyi adók rangsorolásában is (Maros megye a 13., Kovászna a 21., illetve Hargita megye a 24.).

A központi költségvetéstől való függést nem csak az magyarázza, hogy az egy före jutó saját források közti eltérés ötszörös, míg az összjövedelem/fö közti eltérés csupán kétszeres ${ }^{7}$, hanem az is, hogy a saját források aránya a GDP-hez viszonyítva messze elmarad a fejlett országok átlagától, ami elérheti akár a $25 \%$-os részarányt is. Romániában a saját források GDP aránya 2005-ben alig haladta meg az 1\%-ot (Voinea 2006). 
Romániában a saját források GDP aránya tehát a fejlett országokéhoz képest igen alacsony. A legnagyobb arányt Ilfov megyének sikerült elérnie, ahol a saját források aránya a GDP 1,9\%-át teszi ki, őt követi 1,8\%-kal Szatmár megye. A székely megyék esetében a legjobb helyezést Maros megye érte el (28.), öt követi Kovászna, majd Hargita megye (31., illetve 32.). Mindhárom megye az országos átlag 1,2\%-os értéke alatt teljesített.

Amíg a fejlett európai országokban a saját források a helyi önkormányzatok számára fontos jövedelmet jelentenek, ezen belül pedig meghatározó a vállalkozások által befizetett adók nagysága, addig Romániában és Székelyföldön a saját források, azon belül pedig a helyi adók kis szerepet töltenek be a helyi közigazgatásban, a vállalkozások által befizetett adók nagysága pedig nagyon alacsony szinten van (Profiroiu 1999). Igaz, hogy a helyi önkormányzatok számára többletforrás teremtődik, de a jelenlegi rendszerben nem ezek az alapvetö források.

\section{Állami transzferek}

A helyi önkormányzati feladatok ellátására, a regionális különbségek mérsékelése érdekében az állam különböző transzferekre kényszerül. A redisztribúció szélesebb értelemben az államháztartás egésze által, makrogazdasági síkon megvalósított jövedelemelosztás. A piac müködése különböző típusú jövedelemegyenlötlenségeket generál (szociális rétegek, foglalkozási csoportok, gazdasági ágazatok, földrajzi területek közötti differenciák). A különbségek kiegyenlítésére az államháztartás bevételek formájában elvonja a gazdasági szereplők által realizált jövedelem egy részét és kiadásai révén meghatározott célokra visszajuttatja azt (Vigvári 2008). A cél az ország gazdasági potenciáljának növelése az elmaradottabb régiók fejlesztése, a munkalehetőségek biztosítása és az életszínvonal növelése révén (Văcărel et al. 2007). A leggyakoribb kormányzati transzfer a kormányzati támogatás. Ennek eredményeként a helyi bevételi rendszer erős függőségbe került a „támogatáspolitikától” és az egyes lobbi csoportok tevékenységének erösségétől. Ez a helyi döntések és azok pénzügyi hátterének megbomlásához vezetett (Lados 1995).

A decentralizációs törekvések ellenére a helyi önkormányzatok nagymértékben fugggnek az állami költségvetési forrásoktól, illetve az állami transzferektől (Hoantă 2000). Az állami transzferek abszolút mértéke alapján Kovászna megye az országos utolsó helyezést érte el, Hargita megye a 28., Maros megye pedig a 14. helyen áll. Érdekes azonban, hogy a közhiedelemmel ellentétben, mely szerint Hargita megyében az állami transzferek nagyon kis arányt képviselnek, az egy lakosra számított kormányzati transzferek alapján Hargita megye a 8 . helyezést érte el (193 euró), őt követi Kovászna megye a 17. (175 euró), illetve Maros megye a 23. (168 euró) hellyel (2.ábra). 


\section{2. ÁBRA}

Az egy lakosra jutó állami transzferek területi megoszlása Romániában, 2005 (euró)

(Territorial Distribution of the Governmental Transfers per

Capita in Romania, 2005, EUR)

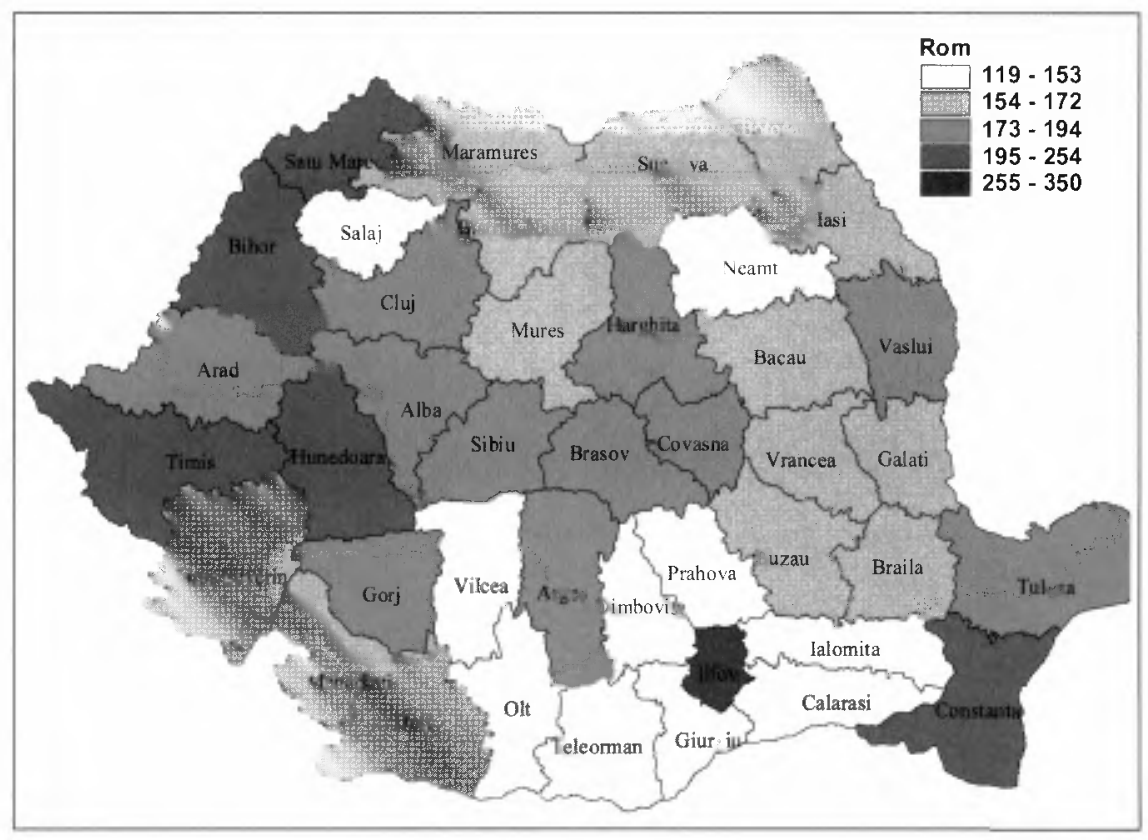

Forrás: A Pénzügyminisztérium által szolgáltatott adatok alapján saját szerkesztés.

Romániában az állami transzferek jelentik a helyi önkormányzatok összjövedelmének kb. 80\%-át. A megosztott bevételek két fö forrásból táplálkoznak. Az ÁFA-ból való visszaosztások adják a kormányzati transzferek nagyobb, $\mathrm{kb}$. 65\%-os részét, míg a fennmaradó rész a személyi jövedelemből való visszaosztásokból származik.

Az ÁFA-ból történő transzferek célirányos támogatások, az önkormányzatok csak a pénzügyi csatorna szerepét játsszák. Az összegeket a 2001-től önkormányzati szintre telepített alapfokú ${ }^{8}$ oktatásban dolgozók bérére, mezőgazdasági tanácsiroda múködtetésére, gyermekvédelemre, távfütési szubvenciókra, megyei és községi utak karbantartására, fogyatékosok támogatására, szociális támogatásra, energetikai központok felújítására, lakossági nyilvántartási feladatok ellátására lehet felhasználni.

$\mathrm{Az}$ ÁFA-visszaosztás legnagyobb részét az alapfokú képzésben dolgozók alapbére jelenti, ez a teljes ÁFA transzfer több mint fele (4. táblázat). Nagyon érdekes a székely megyékben az alapszintủ oktatás támogatásának nagysága. Hargita megye második az egy fớre jutó alapszintủ oktatást támogató transzfer szerint, őt követi Kovászna megye a 4. helyezéssel. Ez elsősorban azzal magyarázható, hogy egy kisebb lakosságú megye ,kiszolgálásához” átlagosan nagyobb számú tanügyi dolgozó szükségeltetik, valamint, hogy Hargita és Kovászna megyében az átlagnál 
nagyobb számú település található kevés számú lakossal. Az átlagosnál nagyobb „tanügyi költség" a nemzetiségi oktatással is magyarázható, egy településen párhuzamosan müködő román és magyar iskola infrastruktúrájának a fenntartása többletköltséget igényel.

\section{TÁBLÁZAT}

A kormányzati transzferek struktúrája Székelyföldön, 2005 (millió euró)

(The Structure of the Governmental Transfers in Szeklerland, 2005, million EUR)

\begin{tabular}{|c|c|c|c|c|c|c|c|c|c|c|}
\hline Megye & Összesen & $\begin{array}{c}\text { Személyi } \\
\text { jövedelem- } \\
\text { adó } \\
\text { transzfer }\end{array}$ & $\begin{array}{c}\text { Összes } \\
\text { ÁFA } \\
\text { transzfer, } \\
\text { ebböl: }\end{array}$ & 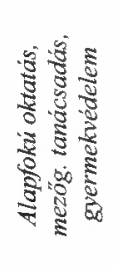 & 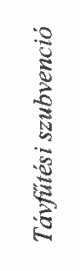 & 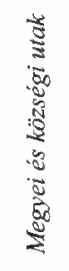 & 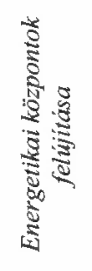 & 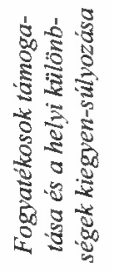 & 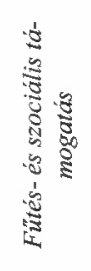 & 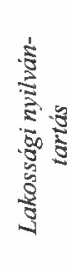 \\
\hline Maros & 97,6 & 28,3 & 69,3 & 44,9 & 0,9 & 1,7 & 1,8 & 17,7 & 2,1 & 0,2 \\
\hline Kovászna & 39,2 & 8,9 & 30,3 & 19,4 & 0,2 & 0,6 & 0,0 & 8,3 & 1,7 & 0,1 \\
\hline Hargita & 63,0 & 12,4 & 50,6 & 30,1 & 1,8 & 1,2 & 1,7 & 13,6 & 2,1 & 0,1 \\
\hline $\begin{array}{l}\text { Románia } \\
\text { összesen }\end{array}$ & 4050,9 & 1422,0 & 2628,9 & 1579,4 & 136,2 & 65,4 & 66,1 & 618,7 & 158,9 & 4,2 \\
\hline
\end{tabular}

Forrás: A Pénzügyminisztérium által szolgáltatott adatok alapján saját szerkesztés.

A megyei és a községi utak karbantartására és felújítására már nem jutott akkora támogatás, de még mindig az átlagnál nagyobb. Azonban itt csalóka az egy före számított mutató, ugyanis az útjavítást inkább az utak átlag hosszához kellene viszonyítani. Ha az egy km-re eső visszaosztást vizsgáljuk, Hargita megye a 35., Kovászna megye a 30., Maros megye pedig a 11. (5. táblázat). Ez a helyezés hủen tükrözi az utak rossz minőségét Hargita és Kovászna megyében. Ezt fokozza a szomszédos Brassó megye rossz helyezése is (36.), ahol a két székely megye felé irányuló összekötő megyei utak minősége jóval rosszabb az átlagnál.

Félrevezető lehet a lakossági nyilvántartás rangsora is, hiszen ezt az intézményt kiszolgáló személyzet száma nem arányosan nỏ az ellátott lakosság növelésének számával.

Az egy före jutó távfütési szubvenciók, a közhiedelemmel ellentétben, mindhárom megyében az átlag alatt vannak. Ez föleg Hargita megyében érdekes, mert a „hideg pólusaként" számon tartott térség az átlagnál kevesebb összeget kapott 2005-ben (ebben az évben Gyergyószentmiklóson nem volt még földgáz-ellátás).

A másik nagy kormányzati megosztott bevételi tétel a személyi jövedelemadóból származik, amely a teljes átutalások mintegy $35 \%$-át adja.

Egyes szakkönyvek a személyi jövedelemtranszfereket a saját forrásokhoz sorolják, azonban a törvény szerint ezek az adók az állami költségvetés részét alkotják, amelyekböl a hónap végétól számított 5 munkanapon belül a következő visszaosztásokat kell megvalósítani:

- az egyes települések által befizetett teljes személyi jövedelemadó $47 \%$-át az a városi és községi önkormányzat kapja, amelynek területén ez az adó képződött, 
- a személyi jövedelemadó 13\%-a a megyék önkormányzatát illeti,

- ennek 22\%-a pedig a helyi önkormányzatok céljaira, az Állami Kincstárnál levő helyi pénzügyek számlájára kerül.

Ezek az arányok Bukarest esetében változnak ${ }^{10}$, a visszaosztott százalék azonban mindkét esetben ugyanannyi, vagyis $82 \%$.

\section{TÁBLÁZAT}

Egy före esö kormányzati transzferek, 2005 (rangok)

(Governmental Transfers per Capita in 2005, Ranks)

\begin{tabular}{|c|c|c|c|c|c|c|c|c|c|}
\hline Megye & $\begin{array}{l}\text { Személyi } \\
\text { jövedelem- } \\
\text { adó transz- } \\
\text { fer }\end{array}$ & $\begin{array}{c}\text { Összes } \\
\text { ÁFA } \\
\text { transzer, } \\
\text { ebböl: }\end{array}$ & 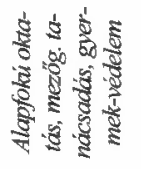 & 密 & 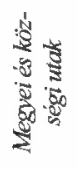 & 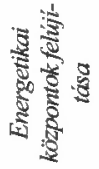 & 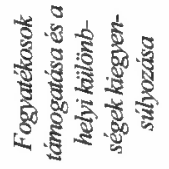 & 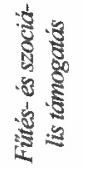 & 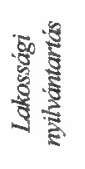 \\
\hline Maros & 16 & 27 & 12 & 37 & 28 & 17 & 23 & 42 & 2 \\
\hline Hargita & 22 & 3 & 2 & 15 & 14 & 5 & 4 & 32 & 6 \\
\hline Kovászna & 21 & 10 & 4 & 38 & 27 & 40 & 12 & 23 & 4 \\
\hline Átlag ${ }^{9}$ & 11 & 23 & 25 & 14 & 26 & 18 & 27 & 26 & 18 \\
\hline
\end{tabular}

Forrás: A Pénzügyminisztérium által szolgáltatott adatok alapján saját szerkesztés.

A helyi önkormányzatok céljaira a helyi pénzügyek számlájára utalt 22\%-ból 27\% a megyei önkormányzat jövedelme. A fennmaradó $73 \%$-ból $20 \%$ a megyei tanács döntése alapján helyi fejlesztési, infrastrukturális és különböző szociális programok finanszírozását szolgálja, a hátramaradt $80 \%$ pedig a helyi pénzügyi hivatal dőntése alapján osztódik szét, figyelmébe véve az egyes város, község lakosságát, nagyságát (település területét) és az egyes önkormányzatok pénzügyi kapacitását.

Ezt azonban a Helyi Pénzügy igazgatósága dönti el egy matematikai képlet alapján, ami nem veszi figyelembe az egyes települések tényleges szükségletét és torzíthat is, hiszen a képlet nem tesz különbséget olyan települések között, ahol sokan laknak kis területen vagy kevesen nagy területen.

A személyi jövedelemadó transzferek szempontjából mindhárom székely megye az átlag alatt teljesített (5. táblázat), a legtöbb személyi jövedelemadót Maros megye termelte. Ha a személyi jövedelemadót a GDP-hez hasonlítjuk, a fentebb említett megyék helyezése romlik. Maros megye hátrakerül a 20., Kovászna a 27., Hargita megye pedig a 29. helyre. A helyezés romlását véleményünk szerint a GDP-nél jóval gyengébben teljesíto bruttó bérek okozzák. Bruttó bérek szerinti rangsorolásban Kovászna megye az ország utolsó megyéje, Hargita a 37., Maros megye pedig a 20. Mindhárom megyében az átlagbérek több mint 10\%-kal vannak az országos átlag (267 euró) alatt. Érdekességnek számít az is, hogy Kovászna és Neamţ megye az ország egyedüli két megyéje, ahol a nőknek nagyobb az átlagfizetése, mint a férfiaknak. Ez Kovászna megyében az átlagosnál jobban fejlett készruha és textiliparnak köszönhető, ahol a női munkaerő keresettsége felfele mozdítja el a bérezést. 


\section{Összefoglalóként}

Tanulmányunkban a romániai helyi önkormányzatok forrásrendszere került elemzésre, amelyen belül poziciónáltuk a székelyföldi megyéket a saját forrásaik, helyi adók és kormányzati transzferek nagysága szerint. Az önkormányzati jövedelmeket vizsgálva láthatjuk, hogy az összjövedelemnek kb. $20 \%$-át a saját források, a fennmaradt részt pedig az állami transzferek adják. A saját forrásokon belül a legnagyobb tételt, kb. 70\%-ot, a helyi adók jelentik.

Székelyföldön a legnagyobb egy főre jutó önkormányzati jövedelmet Hargita megye könyvelheti el magának (10. hely), Kovászna megye a 16., Maros megye pedig a 17. helyen áll. Mindhárom székely megye azonban az országos átlag alatt van. Ha a saját források nagyságát vizsgáljuk, a rangsor változik, Hargita megye a leggyengébb székelyföldi megyének bizonyul (24.), Kovászna megye a 22., az átlagosan sürün lakott Maros megye a 14. A vizsgált székely megyék hasonló helyezéseket értek el az egy före eső helyi adók rangsorolásában is.

Az önkormányzati saját források nagysága a fejlett országokéhoz képest nagyon alacsony. Habár Bukarest esetében a saját források GDP aránya eléri a 2\%-ot, az országos átlag csupán 1,2\%. Mindhárom székelyföldi megye az országos átlag alatt teljesített, a legjobb helyezést Maros megye érte el (28.), őt követi Kovászna, majd Hargita megye (31., illetve 32.).

Habár a saját források vizsgálatánál Hargita és Kovászna megye is az országos rangsorolásban a gyengébb megyékhez tartozott, az önkormányzati jövedelmek $80 \%$-át alkotó állami transzferek alapján Hargita megye nagyon jó, 8. helyezést ért el (193 euró), őt követi Kovászna megye a 17. (175 euró) hellyel. Maros megye az egy főre eső 168 euróval a 23. Székelyföldön tehát a kevesebb saját forrással rendelkező két megye több, a nagyobb saját forrással rendelkező Maros megye pedig kevesebb állami transzferhez jutott.

\section{Jegyzetek}

${ }^{1}$ Az unitárius rendszert a kormányzat egyetlen szintje jellemzi, nincsenek helyi kormányzatok, amelyek a központi kormányzattól függetlenül cselekednének. A szövetségi rendszer olyan kormányzati forma, amely a kormányzati szintek közötti hatalommegosztás elvén alapul (Nemec-Wright 2000).

${ }^{2}$ Az államháztartás legnagyobb költségvetése a 14 milliárd euró nagyságú állami költségvetés (2005) melynek fő forrása az ÁFA (44\%), luxus adók-illetékek (17\%), személyi jövedelemadók és profitadók $(13-13 \%)$.

Exkluzív kompetenciák: törvény által a helyi közigazgatás hatáskörébe tartozó kompetenciák, amelyek gyakorlásáért (teljesítéséért) ők felelnek. A helyi önkormányzatoknak döntési joguk van, és rendelkeznek a feladatok teljesítéséért szükséges forrásokkal és eszközökkel, mindez a törvény által elöirt rendelkezések, standardok és feltételek mellett.

Megosztott kompetenciák: a helyi és az állami közigazgatás bizonyos szintjei (megyei, központi) által közösen gyakorolt kompetenciák, a finanszírozási források, valamint a döntéshozatali jog pontos megosztása mellett. 
Származtatott (leosztott) delegált feladatok: az állami közigazgatási szervek által törvény útján a helyi önkormányzatokra ruházott kompetenciák, a hozzájáró pénzügyi forrásokkal együtt, amelyeket a központilag meghatározott keretek szerint gyakorolhatnak.

4 A helyi adók kategóriában csak a direkt (vagyonadó és egyéb direkt adók) és indirekt adókkal (előadás, jegyadó, egyéb indirekt adók) számoltunk.

5 A személyi jövedelemböl származó források jelen tanulmányban állami transzferként szerepelnek.

${ }^{6} \mathrm{Az}$ indirekt adókat nem soroltuk egyik csoportban sem, mert nem sikerült megtudni, hány százaléka származik jogi személyektöl, illetve a lakosságtól.

${ }^{7}$ Geréb László 2001-es adatokat feldolgozva ugyanerre a következtetésre jutott (Geréb 2003).

${ }^{8}$ Óvodák, napközik, általános iskolák, szakiskolák, líceumok, gimnáziumok és az ezek mellett müködő diákotthonok.

${ }^{9} \mathrm{Az}$ átlagot egy területi egységként vettük. Így a vizsgált egység 41 megye, Bukarest és az, ,átlag”.

${ }^{10} 23,5 \%$ kerül a fỏvárosi kerületek önkormányzatához, $47,5 \%$ a bukaresti munícipiumi önkormányzathoz, $11 \%$ pedig kiegyenlítés céljából a bukaresti pénzïgyek számlájára.

\section{Irodalom}

Anuarul Statistic al României. (1995-2008) (Romániai Statisztikai Évkönyvek) Institutul Naţional De Statistică, Bucureşti.

Georgescu, M.A. (2009) Administrarea finanţelor publice şi a bugetului. (A közpénzügyek és az állami kóltségvetés irányítása) Editura Pro Universitaria, Bucureşti.

Geréb L. (2003) Önkormányzati finanszírozás. - Horváth Gy. (szerk.) Székelyfóld. Dialóg Campus Kiadó - MTA Regionális Kutatások Központja, Budapest-Pécs. 371.-395. o.

Hoanţă, N. (2000) Economie şi finanţe publice. (Gazdaság és közpénziigyek) Editura Polirom, laşi.

Inceu, A.-Dan, T.L. (2006) Finanţe şi bugete publice. (Költségvetés és közpénzügyek) Editura Accent, Cluj Napoca.

Lados M. (1995) Ingatlanvagyon adóztatás az önkormányzati gazdálkodásban. Kézirat, MTA Regionális Kutatások Központja, Győr.

Moșteanu, T. (2002) Finante publice, note de curs şi seminar. (Közpénzügyek, kurzusanyag) Editura Tribuna Economică, Bucureşti.

Moşteanu, T. (2004) Buget şi Trezorerie publică. (Állami költségvetés és kinestár) Editura Universitară, Bucureşti.

Nemec, J.-Wright, G. (2000) Közösségi pénzügyek: Elmélet és gyakorlat a közép-európai átmenetben. Aula Kiadó, Budapest.

Profiroiu, A. (1999) Dezvoltarea economică locală. (A helyi gazdasági fejlödés) Editura Economică, București.

Stancu, I. (2007) Finanţe. (Pénzügyek) Editura Economică, București.

Tatu, L.-Panaite, I.A. (2002) Finante locale şi instituţi publice. (Helyi közpénzügyek és a közintézmények) Editura ANER, Bucureşti.

Tulai, C. (2007) Finanțe. (Pénzügyek) Casa Cărții de Ştiinţă, Cluj-Napoca.

Văcărel, I.-Bistriceanu, Gh.D.-Anghelache, G.-Bodnar, M.-Bercea, F.-Moşteanu, T.-Georgescu, F. (2007) Finante publice. Ediţia a VI. (Közpénzügyek) Editura didactică şi pedagogică, Bucureşti.

Vigvári A. (2008) Pénzügy(rendszer)tan. Akadémiai Kiadó, Budapest.

Voinea, G.M. (2005) Finante locale. (Helyi közpénzügyek) Editura Junimea, Iaşi. 